\title{
Legitimacy, Euroscepticism \& Identity in the European Union - Problems of Measurement, Modelling \& Paradoxical Patterns of Influence
}

\author{
Michael Bruter
}

\begin{abstract}
In the past 10 years, an increasing number of social scientists and communication specialists have tried to understand how political institutions and the mass media attempt to - and often seemingly manage to - influence political identities. This body of literature has resulted in some tremendous progress in our understanding of multiple identities, identity change, and theories of communication, but in the context of European identity, there seems to be a distinct breakdown in communication between specific studies of European identity, and more general analyses of European public opinion and Europeans' political behaviour. This article argues that a strongly emerging European identity may in fact be responsible for a number of recent developments in European public opinion and electoral behaviour that many authors have perceived as paradoxical, or simply chosen to ignore because they seemed to go against our traditional categories of analysis, such as Euroscepticism and democratic fatigue. However, this article suggests that this role of identity has been misevaluated because of some significant problems relating to the measurement, causation analysis, and interpretation of European identity as a concept and as an operational variable. This article focuses on some of these key problems, highlights some critical and often unexplained paradoxes, and proposes a few essential notions when it comes to the conceptualisation and operational measurement of political identities, as well as the evaluations of what affects them.
\end{abstract}

IN 2005, FRENCH AND DUTCH CITIZENS DEFIED THE ORIGINAL PREDICTIONS OF A vast majority of analysts by voting against a proposed 'Treaty establishing a Constitution for Europe' in two popular referenda just a few days apart. These shock results have opened a can of worms of competing interpretations, many of which remain either unsubstantiated or merely backed by some relatively limited data. Using the traditional models of second order votes on European questions (Leduc 2002), a number of analysts predominantly focused on how much a vastly unpopular government cost to the referendum. Others have come to the conclusion that European citizens merely showed an 'obvious' lack of European identity, unprecedented levels of Euroscepticism, or a general sense that integration has gone further politically than what citizens desired as they would prefer a more 'technical' and economic integration. In many ways, such is indeed the doubtful interpretation followed by European institutions themselves as well as the heads of states and governments who thought, for reasons that belong to them alone, that deleting the section on symbols of the European Union (EU) (one of the single most popular aspects

The author would like to thank Sarah Harrison for her help and suggestions on this manuscript

ISSN 1815-347X online. Bruter, M. (2008). 'Legitimacy, Euroscepticism \& Identity in the European Union - Problems of Measurement, Modelling \& Paradoxical Patterns of Influence', Journal of Contemporary European Research, Vol. 4, No. 4, pp. 273-285. Available:

http://www.jcer.net/ojs.index.php/jcer/article/view/153/120 
of the dead constitution), they would reconcile citizens with a new, less ambitious text. Regardless of what political science will identify as the ultimate cause, these results and the ensuing crisis have shaken our understanding of whether a mass citizen identity is emerging to mirror the 'ongoing, progressive' identity of the EU (Caporaso 2005) as, in the absence of fully democratic institutional structures, an underlying identity has often been deemed a necessary condition to the legitimacy of an increasingly political and institutionalized project (see discussion in Bruter 2005). Rather than assume some indirect identity meanings and implications of citizens' behaviour without directly measuring it, this article is concerned with how scholars can go about to assess whether Europeans feel European, why some citizens 'feel' more European than others, and what are the attitudinal and behavioural implications of identity, particularly in terms of Euroscepticism and public attitudes towards European integration.

\section{Citizenship and Identity in the European Union}

Indeed, the emergence and deepening of an EU citizenship has been a key aspect of integration over the past two decades, and one which seems to have been consistently praised by citizens even in the most Eurosceptic countries. How can we reconcile this with an unprecedented number of 'no' votes in referenda on EU questions in Denmark, Ireland, France, and the Netherlands over the past 15 years? How can we unify the two mirrored debates on what being European means and should mean? The question of who feels European at heart, what it means, and what it implies has tremendous implications for our understanding of complex multiple identities in the EU and beyond but also questions relating to the legitimacy of the European Union as a political system. Within the context of this quest, the excellent progress recently made in terms of analysing problems with the institutional features of the European Union (see for instance Hix 2008) cannot really be connected to in-depth analyses of public perceptions because of the appalling quality of the measures of public opinion on Europe and even more disastrous measures of identity that are easily available. In many ways, from a scholarly perspective, this imbalance should be intellectually unacceptable considering that attitudes towards European integration probably benefit from more survey questions than almost any other public opinion question.

This article revisits some of the key problems faced by scholars specialising in the study of European identity, and attitudes towards integration including Euroscepticism in conceptual terms, in terms of methods and measurement, and in terms of modelling and analysis of causality. The article starts by looking at some of the key progress made by the literature on the notion and nature of European identity and its relationship with citizenship. It then questions the 'common' perception that since Euroscepticism 'seems' to be high, identity must be low by attracting our attention to a number of paradoxical attitudes towards integration in the past few years. The article then evaluates some of the key problems we face in terms of the measurement and characterisation of identity, (very) critically assessing the main measures currently used in mass surveys such as the European Commission's EU-wide public opinion survey Eurobarometer, and proposing some alternatives to these common measures. The article concludes with a look at a number of problems of modelling faced by political scientists when it comes to understanding both the nature of what influences identity, and its implications in terms of attitudes towards integration and questions of behaviour, highlighting how some major paradoxes could be answered by a more critical and rigorous measurement of European identity.

\section{European Identity in Context}

In the past 10 years, research on both European citizenship and European identity has accelerated to add much to our knowledge of what it means - both in terms of rights and in terms of perceptions - to be a European and a citizen of the EU. The literature on 
EU citizenship has progressed in different directions. Authors such as Meehan (1993), Wiener (1998), Bellamy and Warleigh (2005) and Strudel (2007) have mostly focused on what EU citizenship actually entails, the new rights it grants to citizens, and how it is practiced, sometimes focusing on the implications of very specific ones (for instance, in Strudel's case, the practice of citizens' right to vote in their country of residence). By contrast, Bellamy, Castiglione et al. (2006), Mokre, Weiss, Bauböck et al. (2003), and Déloye and Bruter (2007) have helped us a lot to progress in our understanding of the philosophical origins, and symbolic and political implications this new citizenship has particularly on national citizenship alongside which it has emerged.

The study of the symbolic and political implications of the development of EU citizenship naturally opened the way to a consequential progress of academic explorations of the world of European identity. On the whole, the social sciences in general and political science in particular were slower to take a rigorous interest in European identity as compared to citizenship, probably because of the difficulties that we will discuss when it comes to empirical studies of identity and in particular to its quantitative measurement. In political science, the first to show an interest in European identity were post-materialists (Inglehart 1997), who, as explained, saw in it a form of cosmopolitanism which would be opposed to national identity. This perspective, however, put political science directly at odds with the findings of social psychologists such as Mummendey and Waldzus (2004) and Breakwell (2004) who suspected that far from being opposed, European and national identities would be part of the same quest for identity definition. Their intuition was confirmed by Duchesne and Frognier (1995), while researchers such as Herrmann et al. (2004) tried to relate these psychological theories of identities to models of coexistence of multiple identities, such as Risse's famous distinction between 'marble cake' and 'Russian dolls' models. These have later been empirically confirmed, for instance by Bruter (2009) who finds that on the whole there is a positive correlation between citizens' European and national identities of the order of 0.19 (and similarly high positive correlations between European and regional and local identities respectively).

The link between European and other identities is not the only one that has puzzled social scientists in recent years. A large number of studies have started to look at the extent to which political institutions, history, culture, experience, and the mass media have played a role in shaping an emerging European identity and at the impact that they could have in the future. A smaller but important body of literature is also starting to think about the possible impact this emerging identity has on some patterns of public opinion and patterns of behaviour that might be affected by it over time.

\section{Paradoxes of Popular Legitimacy}

There we face an interesting paradox. The bulk of popular elite interpretations - from the mass media to many political parties through to EU institutions themselves, is that EU citizens don't feel European, that Euroscepticism is paradoxically on the rise and has led to a recent string of 'no votes' in referenda on EU questions, that turnout in European Parliament elections keeps declining and betrays a disaffection of citizens for an EU which is, consequently, supposed to face a widespread and dangerous crisis of legitimacy at the moment. In fact, a significant number of quality academic publications accept this interpretation (Cederman 2001; Hix 2008).

While not questioning the fact that European integration is indeed facing a crisis of legitimacy in the sense of a mismatch between public preferences in terms of European integration and what is actually proposed to them by their elites, the assumption that this must mean a rise in anti-EU sentiment and a lack of European identity of citizens is less than obvious. In fact, there are as many signs pointing out to a rise in general support for the European project, civic engagement, and European identity alike as there are signs of dissatisfaction with specific aspects of integration. 
Our suggestion here is that European identity is in fact growing, but that because an increasing number of EU citizens precisely feel European, they now judge the various policies and institutional reforms of the EU 'from the inside', as citizens, and thus on their own merits, rather than on the principle of integration. Thus, we would not be witnessing a lack of European identity and rise in Euroscepticism, but an increasing European identity and switch from an 'outside' Euroscepticism that targets the principles of integration to an 'inside' Euroscepticism that takes the principle of durable, continuing integration for granted but targets specific policies and reforms. This would explain some paradoxical evolution in European opinion.

For instance, the turnout in European Parliament elections between 1999 and 2004 among EU member states that voted on both occasions went up, with the overall decline in turnout being fully explained by the enlargement of the EU to a number of countries where turnout was extremely low. Moreover, Franklin (2001) has shown that the decline in overall turnout in European Parliament elections since the 1970s is caused almost solely by structural factors, suggesting that it is not in any way sharper or more worrying than for national level elections in the same countries.

The argument of the recent victory of the 'no' in a number of referenda on questions relating to the European Union is equally weak. The most emblematic of these 'No votes' - that of the French population in May 2005 - occurred at a time when support for European integration was at its peak (European Commission 2005: 93). Similarly, for the first time in the history of French referenda on EU questions, the dominant argument of the 'no' camp, regardless of its (lack of) credibility was based not on a rejection of integration - or a claim for slower integration - but instead, on a claim for faster and more generalised integration that would be increasingly social and political. Indeed, many leaders of the 'no' campaign on the left, such as Laurent Fabius or Benoit Hamon, promised voters that if the 'no' won, the treaty would be renegotiated, with greater emphasis on 'social Europe' and political integration rather than economic integration which they perceived as dominant in the text.

Finally, the question of popular legitimacy is hard to disconnect from the question of institutional trust. There again, the evolution of public opinion when it comes to trust in EU institutions since the early 1980 s is highly symptomatic. Twenty-five years ago, there was no EU country where EU institutions were globally more trusted than their national equivalent. By the mid-2000s, however, almost all of the 'old' member states and a large majority of the new ones trust the European Commission more than their national government, and the European Parliament more than their national one (table 1 [page 277] and table 2 [page 278]). The only exceptions tend to be Sweden and, to a lesser extent, Denmark (Parliament only) and Finland (where the scores for national Parliament and the European Commission are tied). For the tenants of wide-spread Euroscepticism, this is a shocking truth. Who would think that in thirteen of the fifteen old member states, including the United Kingdom, the European Commission is in fact significantly more trusted than the national government? And how can we reconcile these findings with suspicion of declining popular legitimacy and never emerging identity?

The simple answer is that most of the models that conclude to widespread Euroscepticism and minimal European identity rely on measures which truly capture neither. When it comes to the evolution of average levels of European identity across the member states since 1971, Bruter (2005) shows that mass European identity has significantly progressed everywhere throughout the period (with the exception of Germany around the unification period and Luxembourg where it was already very high and has remained stable). 
The progress of European identity thereby identified is much sharper than using Eurobarometer's Moreno question' as done by Duchesne and Frognier (1995) or Citrin and Sides in Herrmann et al. (2004).

\begin{tabular}{|c|c|c|c|}
\hline \multicolumn{4}{|c|}{$\begin{array}{c}\text { Table 1: Compared Trust in the European Commission and National } \\
\text { Government (\%) }\end{array}$} \\
\hline COUNTRY & $\begin{array}{l}\text { EUROPEAN } \\
\text { COMMISSION }\end{array}$ & $\begin{array}{c}\text { NATIONAL } \\
\text { GOVERNMENT }\end{array}$ & DIFFERENCE \\
\hline Poland & 49 & 7 & +42 \\
\hline Italy & 63 & 26 & +37 \\
\hline Slovakia & 54 & 17 & +37 \\
\hline Belgium & 63 & 34 & +29 \\
\hline Hungary & 58 & 31 & +27 \\
\hline Slovenia & 52 & 27 & +25 \\
\hline France & 52 & 29 & +23 \\
\hline Ireland & 61 & 39 & +22 \\
\hline Portugal & 56 & 34 & +22 \\
\hline Germany & 39 & 23 & +16 \\
\hline Netherlands & 54 & 39 & +15 \\
\hline Lithuania & 45 & 31 & +14 \\
\hline Spain & 53 & 42 & +11 \\
\hline Czech Republic & 35 & 25 & +10 \\
\hline Greece & 63 & 55 & +8 \\
\hline Austria & 47 & 39 & +8 \\
\hline United Kingdom & 26 & 19 & +7 \\
\hline Luxembourg & 66 & 61 & +5 \\
\hline Latvia & 32 & 28 & +4 \\
\hline Denmark & 47 & 44 & +3 \\
\hline Malta & 50 & 49 & +1 \\
\hline Sweden & 48 & 48 & 0 \\
\hline Finland & 59 & 59 & 0 \\
\hline Estonia & 44 & 45 & -1 \\
\hline Cyprus & 49 & 75 & -26 \\
\hline \multicolumn{4}{|c|}{$\begin{array}{l}\text { Figures in the first two columns correspond to the proportion of citizens who tend to trust the } \\
\text { institution. Figures in column } 3 \text { correspond to the trust advantage }(+) \text { or disadvantage }(-) \text { of } \\
\text { the European Commission when compared to the national government. Source: Compiled by } \\
\text { the author from Eurobarometer } 61 \text { data, tables } 4.1 \mathrm{~b} \text { and } 8.4 \text { (European Commission 2004). }\end{array}$} \\
\hline
\end{tabular}

When it comes to individual level models, many authors use questions on support for integration and perceived benefits from integration as a 'proxy' for European identity (the advantage of these two questions is that they are systematically used in every Eurobarometer, thus allowing some consistent time series analysis), or use the above mentioned Moreno question. The problem is that when it comes to understanding what goes on in the minds of people, questions matter - a lot. Retrospectively evaluated, perceived benefits from integration are not the same thing as support for European integration in principle, and neither do they indicate European identity. And in truth, the Moreno question is not a nearly acceptable measure of European identity either.

\footnotetext{
1 'in the near future, do you see yourself as - Nationality only, Nationality and European, European and Nationality, or European only.'
} 
As it happens, we are thus faced with a maelstrom of imprecise or inaccurate measures of European identity, and invalid measures can only lead to biased models. In the next section, I go further in analysing the scope of the problem faced by the literature when using 'standard' measures and proxies for European identity and think about its likely consequences in conceptual and empirical terms.

\begin{tabular}{|c|c|c|c|}
\hline \multicolumn{4}{|c|}{$\begin{array}{c}\text { Table 2: Compared Trust in the European Parliament and National } \\
\text { Parliament (\%) }\end{array}$} \\
\hline COUNTRY & $\begin{array}{l}\text { EUROPEAN } \\
\text { PARLIAMENT }\end{array}$ & $\begin{array}{l}\text { NATIONAL } \\
\text { PARLIAMENT }\end{array}$ & DIFFERENCE \\
\hline Poland & 53 & 8 & +45 \\
\hline Slovakia & 59 & 19 & +40 \\
\hline Italy & 68 & 32 & +36 \\
\hline Hungary & 64 & 29 & +35 \\
\hline Slovenia & 59 & 25 & +34 \\
\hline Lithuania & 52 & 19 & +33 \\
\hline Belgium & 64 & 38 & +26 \\
\hline Czech Republic & 44 & 18 & +26 \\
\hline Ireland & 64 & 40 & +24 \\
\hline France & 57 & 35 & +22 \\
\hline Germany & 51 & 29 & +22 \\
\hline Portugal & 58 & 37 & +21 \\
\hline Spain & 62 & 42 & +20 \\
\hline Latvia & 40 & 20 & +20 \\
\hline Netherlands & 57 & 43 & +14 \\
\hline Estonia & 49 & 35 & +14 \\
\hline Luxembourg & 67 & 56 & +11 \\
\hline Malta & 55 & 47 & +8 \\
\hline Greece & 70 & 63 & +7 \\
\hline United Kingdom & 30 & 25 & +5 \\
\hline Finland & 61 & 58 & +3 \\
\hline Austria & 43 & 41 & +2 \\
\hline Sweden & 55 & 58 & -3 \\
\hline Denmark & 55 & 63 & -8 \\
\hline Cyprus & 55 & 74 & -19 \\
\hline \multicolumn{4}{|c|}{$\begin{array}{l}\text { Figures in the first two columns correspond to the proportion of citizens who tend to trust the } \\
\text { institution. Figures in column } 3 \text { correspond to the trust advantage }(+) \text { or disadvantage }(-) \text { of the } \\
\text { European Commission when compared to the national government. Source: Compiled by the } \\
\text { author from Eurobarometer } 61 \text { data, tables } 4.1 \mathrm{~b} \text { and } 8.4 \text { (European Commission 2004). }\end{array}$} \\
\hline
\end{tabular}

\section{Empirically Approaching the Concept of European Identity}

In many ways, a number of these conceptual breakthroughs on the relationship between elites, media, citizenship, legitimacy, and identity have been met by a methodological 'wall' because of problems in capturing European identity. In fact, in the past 10 years, an increasing number of works have given rise to parallel efforts to criticise the poor quality of the instruments currently available to measure identity, and to provide some viable alternatives to further investigate how European the Europeans 
feel. Most of the first such models were qualitative. Researchers such as Meinhof and Galasinski (2005), Grundy and Jamieson (2007), and Bruter (2004), respectively made border Europeans, young Europeans, and Europeans in general, talk about their identity, reaching complementary results. Meinhof and Galasinski find that without prompting, border citizens seldom mention Europe, but Grundy and Jamieson and Bruter find that their respondents have spontaneous ideas about their Europeanness. These interesting but complex results have reinforced the perceptions of many that better quantitative instruments were needed. This need is pointed out by McLaren (2006 and 2007), Déloye and Bruter (2007), and implicitly in van der Eijk and Franklin (1996) and van der Brug and van der Eijk (2008). Herrmann et al. (2004) and Bruter (2005, 2009) discuss various ways in which such quantitative models can be conceptualised and operationalised.

Of course, there is no doubt that political identities are remarkably difficult to measure. We showed that apart from the specific flaws that plague the two main questions used to capture European identity, all self-placement questions will first and foremost face the problem of the 'language prison' identified by Burgess (in Herrmann et al. 2004). That is, identity is not naturally thought of in analytical terms, but lived and at best expressed. Bruter (2009) finds that even its expression is contextualised. Indeed, his results show that while many intuitively suspect that the 'real' identity of citizens might be revealed by spontaneous expressions, this is not quite true. Thus, when simply asked 'where do you come from?', respondents' answers are highly contextualised and fully integrate the categories the interlocutor is expected to ask about. Thus, if a Londoner is asked this question by a German, (s/he is likely to answer 'from Britain', if the interviewer is British 'from London', and if the interlocutor is a Londoner her/himself 'from (say) Camden'. Of course, these three different answers correspond in no way whatsoever to sudden changes in the respondent's identity. In this sense, the entire difficulty of measuring identities quantitatively consists of finding some operational variables that 'trap' respondents' answers on directly comparable scales, that correspond to sub-aspects of identity that are meaningful to large numbers of respondents.

The alternative model developed by Bruter (2003 and 2005) thus distinguishes between two conceptually and empirically distinct components of identities: civic and cultural. These pillars correspond to the broad theories used by political scientists over time to define what constitutes a nation or a political community. These are based on the three main perspectives that have been used since the $18^{\text {th }}$ century to characterise the foundations of the legitimacy of political communities. The first, derived from the French Enlightenment and the 1776 American and 1789 French Revolutions, links the legitimacy of political communities to the very existence of political institutions that are implicitly accepted by society through a social contract (Rousseau 1762). The second, developed by German political thinkers such as Fichte (1845) and Herder (1913) links the legitimacy of political communities to a corresponding 'nation', defined by a common culture (and principally, for Fichte and Herder, a common language). Finally, the third conception, formalised by Renan in 1882, leaves the sphere of objective commonalities between members of a nation to associate its legitimacy to the 'common desire to live together' of its members.

From these three theories, it is easy to derive competing interpretations of the identification of individuals to a political community. First, a 'cultural' pillar corresponds to a citizen's sense of belonging to a human community, with which s/he believes s/he shares a certain common culture, social similarities, ethics, values, religion, or even ethnicity, however defined. A second 'civic' pillar corresponds to a citizen's identification with a political system, that is, an acknowledgement that this political system defines some of her/his rights and duties as a political being. Finally, a third overarching aspect of identity is its general or spontaneous self-assessment, that is, whether or not the individual 'feels' European, in a way that could relate to the civic and/or cultural components of identity. 
Rather than assuming that political identities are one or the other, the contention made here is that the two components of political identities exist in parallel in citizens' minds and should simply be differentiated conceptually and empirically whenever possible.

\section{A Measurement Problem?}

This model contrasts with the logic of the items traditionally used in most mass surveys to measure European identity. Indeed, as explained earlier, a number of authors agree that the problems with these dominant existing measures are and that Eurobarometer and other surveys provide information that is plagued by critical validity problems and fail to offer usable information. Let us now consider these dominant measures.

Eurobarometer and most other studies, including the European Value Survey (EVS) primarily try to capture European identity using the 'Moreno' question (see discussion in Deloye and Bruter 2007). The argument suggesting that this question is highly flawed relies on the following elements:

1. The Moreno scale assumes a tension (negative relationship) between national and European identities. Post-materialist theory used to see European identity as a form of cosmopolitanism and, ultimately, a 'non-identity' (Herrmann et al. 2004). However, as explained earlier, this has been empirically disproved: Duchesne and Frognier 1995; Bruter 2005 \& 2009, and a number of others have all found national and European identities to be positively correlated - in other words, the more Dutch one feels, the more European s/he likely feels, not the opposite. Consequently, the assumed tension around which the question is built is not merely hypothetical but actually empirically disproved;

2. Conversely, the scale is purely comparative between the two possible identities, and forbids expressions of varying strengths of either identity (of two people who feel 'European only', one could feel very European, one almost not at all);

3. Indeed, the question does not allow for 'neither national nor European' as an answer either. This again goes against what we know of identities based on the social psychology literature (see first section of this article);

4. The scale assumes that seeing oneself as 'Dutch and European' means feeling more Dutch and less European than seeing oneself as 'European and Dutch' despite the conjunction 'and' not specifically implying a comparison or inequality. When piloting the question on a sample of approximately 1200 respondents in six countries (UK, France, Germany, Belgium, Portugal, and Sweden) conducting both surveys and follow up focus groups, the findings showed that in focus groups, a majority of respondents claim not to think of 'European and national' as meaning more European than national (or the reverse). Even more symptomatically, however, while including the question in a survey with a split sample whereby possible answers are ordered in opposite ways, we find that reversing the order of the proposed answers dramatically changes the distribution ${ }^{2}$ of respondents, which severely questions the robustness of the survey item;

\footnotetext{
2 With full randomisation of experimental samples, in 6 countries, distributions were as follow

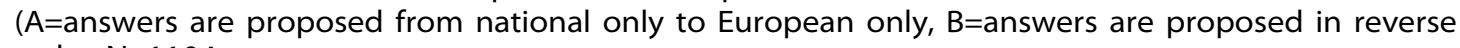
order. $\mathrm{N}=1104$ :

$\begin{array}{lcccc} & \text { N only } & \text { N+E } & \text { E+N } & \text { E only } \\ \text { A } & 31 & 47 & 16 & 6 \\ \text { B } & 24 & 28 & 38 & 10\end{array}$
}


5. In the same pilot, we show that there are major translation issues for this question. After running a post-pilot focus group in the six countries, it can be noted that in some of them, up to $40 \%$ explained that they understood this question (again, phrased in English as 'in the near future, do you see yourself' rather than 'do you feel') to be about 'objectively' predicting the increasing influence of the EU, and not about identity.

For all practical purposes, these numerous problems make the Moreno question seriously unusable. Occasionally, EB and other surveys ask, instead, a question on citizens' 'attachment' to Europe, their country, region, and town/village. However, this question is equally problematic. As explained earlier, Burgess thinks of identity as 'prisoner of language'. This makes the quantitative measurement of identity difficult because it is not spontaneously conceived in analytical terms, but at best 'expressed'. It also implies a need to use some questions with labelled scales as opposed to pure selfplacement to compare individuals. Moreover, attachment is not identity. The pilot study focus groups show that, in all six countries, 'attachment' to one's village/town is higher than 'attachment' to the nation, whereas, national identity is higher than selfexpressed local identity. At best, attachment is a proxy for the 'affective' dimension of identity, which is uncorrelated with other identity components. Indeed, Bruter (2009) and Harrison and Bruter (2009b) show that not only is there no correlation between affective and other 'pillars' of identity, but indeed, that in terms of qualitative narratives, identity was almost as likely to be associated with shame as it is to be associated with pride. He in fact proceeds to cite a Norwegian colleague who once claimed to never feel as Norwegian as when he was on a plane ready to leave Oslo and that all fellow Norwegians on board were 'trying to get drunk before the plane even leaves the tarmac'!

Similarly, this attachment question is indeed most susceptible to Burgess's complaint of the 'language prison'. Indeed, two respondents' '4' on a scale from 1 to 7 might mean completely different things, or indeed, the same respondent's ' 4 ' on two of the parallel attachment scales might relate to entirely different forms of identity.

The exact same two reproaches can obviously be addressed to the 'pride' question which has started to be asked occasionally by Eurobarometer since the 1990s. Moreover, to put it simply, conceptually - and empirically, 'identity' and 'pride' are two different things.

In the face of these problems, we experimentally piloted over 30 new items to capture European identity along two sub-dimensions, civic and cultural, to better understand how European people feel, but also what it means to them (Bruter 2005 and 2009; Déloye and Bruter 2007; Meinhof and Galasinski 2000).

The pilot tested the measures, but also their combination to maximise robustness and monitor variance. The validated measures are claimed to make it possible to provide a consistent and realistic radiography of European identity using mass survey components of this project. The pilots were used to model the relationship between the media, symbols of Europe, and the civic and cultural components of European identity, resulting in a more systematic analytical model of the causes and consequences of European identity. The results show that news primarily affects the civic component of European identity, and symbols its cultural component. Bruter (2009) also shows how these effects operate differently over time, and how they interact with ideology, age and education. Finally, identity measured in an electoral context, (Deloye and Bruter 2007; Bruter and Harrison 2009a) seems to affect participation in elections and referenda as well as party choice even though by contrast, we know that support for integration itself has no effect on the likeliness of an individual to participate in European Parliament elections (van der Eijk and Franklin 1996). 
The measures proposed by Bruter (2009) first include proposed measures of the general dimension of European identity. General identity measures are self-placement items, using different formulations, scales, and labelling to allow respondents to express how European they feel and compare this to similar formulations of national, regional, and local identities. A typical example asks respondents 'in general, would you say that you consider yourself "a European"?' using a five point scale for proposed answers. Some of the scales are very similar to the Eurobarometer 'attachment' question mentioned earlier but referring to identification rather than attachment.

The second type of measures aims at capturing respondents' civic identity using various specific references to evaluate how citizens relate to the EU as a political system. These references range from attitudes towards the mention of 'European Union' on passports to perceptions of the EU flag, European elections, border sovereignty, or the EU anthem be played after the national anthem when an athlete from a member state wins a gold medal. A typical example reads: 'Since 1985, citizens from all the countries of the European Union have had a common 'European' passport on which both the name of their country and 'European Union' is written. Do you think that this is a good thing?' with a 5 point scale for proposed answers.

Finally, the third type of measures targets cultural identity items and measures perceptions of belonging to a European 'human' community, of beliefs in shared European values or heritage, and of relative closeness to fellow Europeans vis-à-vis non-Europeans. A typical example of a cultural identity item would read 'Some say that in spite of their numerous differences, Europeans share a 'common heritage' that makes them slightly closer to one another than they are to, say, Japanese or Chilean people. Do you...?' with a five point scale for proposed answers.

\section{European Identity and the Desired Future of EU Citizenship - Bridging the Legitimacy Gap?}

Where does this leave us? Is there any reason to believe that if European identity was properly measured, our understanding of its determinants and effects would indeed be different and open new ways of understanding how European citizens relate to the European Union? After all, as Bruter (2005) notes, all the paradoxes noted earlier that concern (1) European public opinion and (2) Europeans as a voting body might be unrelated to the continuing emergence of a mass European identity. How European identity 'fits' in our more global understanding of citizens politics in the European Union is summarised by the model sketched in figure 1 . The model suggests that in a number of cases, we may be wrongly looking for an impact of support for integration where it is identity which should matter.

\section{Figure 1: Modelling European Integration}

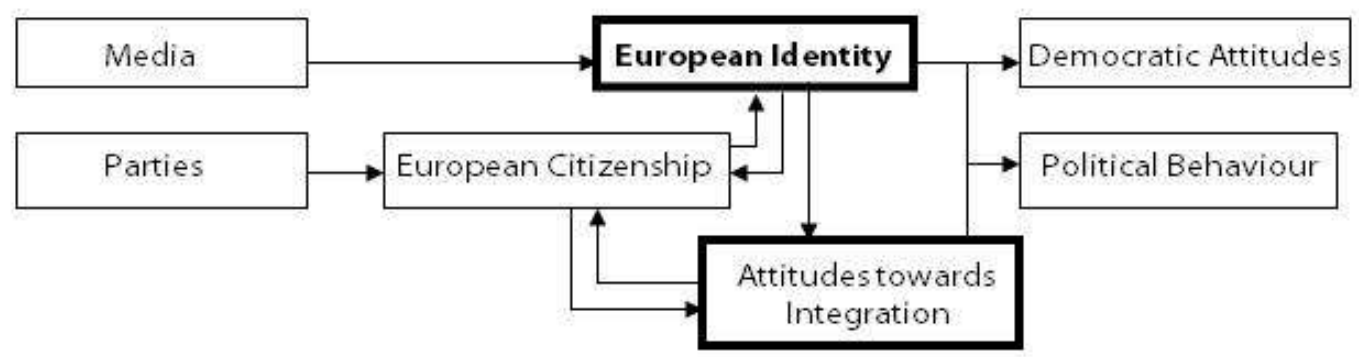


Even more importantly, we suggest that identity is not only caused by citizenship, but desires for the future of citizenship itself, is caused by - and symptomatic of - citizens' identity (Bruter 2009). Here, the argument is that questions on European Union citizenship perceptions and preferences equally need to be rethought to understand not only what it means for citizens to be 'European' but also what they want it to mean in the future. Questions on the expected and desired future evolution of EU citizenship, on what it should mean to our children to be European in 10, 20, or 50 years from now also bring us some essential insight into people's current identity. When it comes to citizens' current understanding of what Europe and being European mean today, they first and foremost refer to borderlessness and free movement, and to the Euro (Bruter 2005 and European Commission 2004). Perceptions that the EU is a bureaucratic machine simply do not come in their vocabulary any more than the notion that the European Union is a 'peace machine'. Being European is being free to move, travel, and live abroad without borders or limitations within the Union, and being a citizen of a political system with its symbols such as the joint currency. When it comes to the future of European citizenship, citizens insist not only on more of the same but on directly electing an EU president in universal elections, participating in EU-wide referenda, and forecast having children who will feel more European than their parents' generation and grand-children who will feel yet more European than them. And this, really, says something about what they do and do not like about European integration, and about how the bulk of contemporary 'Euroscepticism' is fundamentally different from the bulk of Euroscepticism twenty five years ago or the Eurosceptic line of extremist parties. It gives a sense of its 'inside twist' and of what critical citizens take for granted unlike what was the case two or three decades ago.

Contemporary European public opinion is only paradoxical to the extent that one uses old categories, ineffective instruments, and outdated lenses to look at it. The measures of European identity that dominant mass surveys provide us with are such ineffective instruments, and they result in a complete misrepresentation of the true level of European identity amongst the European Union citizenry. The argument made in this article is that the potential consequences of European identity in terms of public attitudes, electoral behaviour, legitimacy, and the understanding of what citizens really want from their new European political system make it essential that, as a discipline, we endeavour to correct these instruments and properly capture European identity to see whether or not it will clear a varnish of apparent paradoxes and unravel a far more straightforward logic of what European Union citizens really want to get from a democratic Union.

\section{References}

Bellamy, R., Castiglione, D., Shaw, J. (eds) (2006). Making European Citizens. Basingstoke: Palgrave.

Bellamy, R. and Warleigh, A. (eds) (2005). Citizenship and Governance in the European Union. London: Continuum.

Breakwell, G. (2004). 'Identity change in the context of growing influence of European Union institutions' in R. Herrmann, T. Risse and M. Brewer (eds), Transnational Identities. Oxford: Rowman \& Littlefield.

Brug (van der), W. and van der Eijk, C. (eds) (2007). European Elections and Domestic Politics. Notre Dame, IN: University of Notre Dame Press.

Bruter, M. (2003). 'Winning Hearts and Minds for Europe: the impact of news and symbols on civic and cultural European identity'. Comparative Political Studies, 36 (10), pp. 1148-1179.

Bruter, M. (2004). 'On what citizens mean by feeling European'. Journal of Ethnic and Migration Studies, 30 (1), pp. 21-41. 
Bruter, M. (2005). Citizens of Europe? The Emergence of a Mass European Identity. Basingstoke: Palgrave.

Bruter, M. (2009 forthcoming). 'Time bomb - news, media, and European identity'. In Comparative Political Studies, 42 (12).

Bruter, M. and Harrison, S. (2009a forthcoming). 'Tomorrow's leaders?' in Comparative Political Studies, 42 (10).

Bruter, M. and Harrison, S. (2009b forthcoming). The Future of our Democracies? Basingstoke: Palgrave.

Caporaso, J. (2005). 'The possibilities of a European identity.' Brown Journal of World Affairs, $12(1)$, pp. 65-75.

Cederman, H. (2001). 'Nationalism and bounded integration: what it would take to construct a European demos.' European Journal of International Relations, 7 (2), pp. 139-174.

Déloye, Y. and Bruter, M. (eds) (2007). Encyclopaedia of European Elections. Basingstoke: Palgrave.

Duchesne, S., Frognier, A-P. (1995). 'Is There a European Identity?', in Public Opinion and Internationalized Governance, O. Niedermayer, R. Sinnott (eds). Oxford: Oxford University Press.

Eijk (van der), C. and Franklin, M. (1996). Choosing Europe. Ann Arbor: Michigan University Press.

European Commission (2004). Standard Eurobarometer 61, Public Opinion in the European Union. Brussels: DG press and Communication. Available at $<$ http://ec.europa.eu/public_opinion/archives/eb/eb61/eb61_en.pdf $>$, last accessed 12 December 2008.

European Commission, (2005). Standard Eurobarometer 63, Public Opinion in the European Union. Brussels: DG Press and Communication. Available at: <http://ec.europa.eu/public_opinion/archives/eb/eb63/eb63_en.pdf $>$, last accessed 12 December 2008.

Fichte, J. (1845). Samtliche Werke. Berlin: Veit Franklin.

Franklin, M. (2001). 'How structural factors cause turnout variations at European Parliament elections' European Union Politics, 2 (3), pp. 309-328.

Grundy, S. and Jamieson, L. (2007). 'European Identities: from absent-minded citizens to passionate Europeans', Sociology 41 (4), pp. 663-680.

Herder, J. (1913). Complete Works. Berlin: Weidmannsche Buchhandlung

Herrmann, R., Risse, T. and Brewer, M. (eds) (2004). Transnational Identities. Boulder: Rowman \& Littlefield.

Hix, S. (2008). What's Wrong with the European Union and How to Fix it?. London: Polity.

Inglehart, R. (1997). Modernization and Post-Modernization. Princeton: Princeton University Press.

Leduc, L. (ed.) (2002). Special issue on referenda - European Journal of Political Research, 41 (2), pp. 711- 888.

McLaren, L. (2007). 'Explaining mass level euroskepticism: identity, interest, and institutional distrust', Acta Politica, 42 (2/3), pp. 233-251.

McLaren, L. (2006). Identity, Interests, and Attitudes to European Integration. Basingstoke: Palgrave.

Meehan, E. (1993). Citizenship and the European Community. London: Sage

Meinhof, U., Galasinski, D. (2005). The Language of Belonging. Basingstoke: Macmillan.

Mokre, M., Weiss, G., Bauböck. R. (eds) (2003). Europas Identitäten: Mythen, Konflikte, Konstruktionen. Frankfurt: Campus.

Mummendey, A. and Waldzus, S. (2004). 'National Differences and European Plurality: Discrimination or Tolerance between European Countries', in R. Herrmann, T. Risse and M. Brewer (eds), Transnational Identities. Boulder: Rowman \& Littlefield, pp. 59-74.

Renan, E. (1882). 'Discours de la Sorbonne in Discours et Conferences. (Discours du 11 mars 1882).

Rousseau, J-B. (1762). Le Contrat Social. Geneve: Rey.

Strudel, S. 2007. 'Citizenship' in Déloye, Y. and Bruter, M. (eds) Encyclopaedia of European Elections. 
Basingstoke: Palgrave

Wiener, A. (1998). European Citizenship Practice: Building Institutions of a Non-State. Boulder: Westview Press.

*** 